\title{
Disaster Development Interface \& its Impact on Emerging Vulnerability Scenario in Ladakh Region of North Western Himalayas
}

\section{Shafi Bhat \\ University of Kashmir}

\section{Amir Ali Khan}

National Institute of Disaster management

MOHMAD AKBAR ( $\square$ mmeer1634@gmail.com )

University of Kashmir https://orcid.org/0000-0003-2144-6936

\section{Mir Sumaira}

University of Kashmir

\section{Research Article}

Keywords: Multi-hazard, Fragile Region, Pristine Environment, AHP-Method, Vulnerability, Mitigation

Posted Date: November 8th, 2021

DOI: https://doi.org/10.21203/rs.3.rs-978382/v1

License: (a) (7) This work is licensed under a Creative Commons Attribution 4.0 International License. Read Full License 


\section{Abstract}

The Union Territory of Ladakh located in the North-Western Himalayan Region is a multi-hazard prone region, highly vulnerable to seismic hazards, landslides, snow-avalanches, flash-floods and cloud bursts. Besides, anthropogenic hazards like border conflicts and political turmoil in neighboring region of Kashmir has resulted in huge economic loss to the region. Findings reveal that despite suffering losses by natural and human -induced disasters, the region has been positively affected by publicity generated by such events. These events managed to showcase the unique physiography, pristine environment and adventurous terrains of Ladakh, which in the subsequent years increased tourism sector as the main growth driver in the region. Furthermore, movies like LOC Kargil and 3 idiots highlighted the potential for adventurous tourism in the region ultimately attracting large number of domestic tourist to Ladakh. The exceptional growth in tourists and associated developmental sectors has resulted in enhanced levels of vulnerabilities in this environmentally fragile region on account of faulty planning practices. The study focuses on geo- physical as well as anthropogenic vulnerability analysis with the help of remote sensing and Analytical Hierarchical Processes (AHP) method. The results reveal that the region is facing an increase in climate change related vulnerabilities followed by geo- physical, socio-cultural and environmental vulnerabilities. The study highlights the need to manage emerging vulnerabilities through proper adaptation and mitigation measures by incorporation of geo physical factors in policy formulation. Proper implementation of these measures can ensure sustainable development in this fragile Himalayan region.

\section{Introduction}

Disasters and development have been part of human experience ever since people started living in stable communities (Bas Van Bavel, 2020). Disaster and development as two contrasting events are undoubtedly related to each other. According to various UNDP reports (UNDP, 2011), disasters and development can either increase or decreases vulnerabilities. Disaster and development events provide opportunities as well as occasional setbacks resulting in physical social and economic impacts (Manyena, 2012). Majority of these events have influenced the people from the very early times (Collins, 2018). Development of ancient civilizations along the major rivers, invention of fire, industrial revolution, and urbanization faced the havoc of disasters like floods, famines, earthquakes, cyclone, tsunamis, plague etc. This led to the development and destabilizing of great civilizations including the Mayons, the Norse, the Old Egyptian Empire, etc (Coppola, 2015).

The development scenario also gets influenced by geo physical and anthropogenic activities which are undergoing an accelerated change thereby increasing the associated risks (Kulatunga, 2010). Uncertainty in daily risks challenges us from various hazard events (Hariri-Ardebili, 2020). It's thus important to incorporate new management strategies to deal with the new emerging challenges in a more effective way (Sawalha, 2020). Hazards like geophysical, meteorological climatological biological, technological, keep on affecting people at an unprecedented scale (Hariri-Ardebili, 2020), (Joel C. Gill, 2014), (Hungsoo Kim, 2013), (luliana Armas, Dragos Toma-Danila, 2017), (Markus Eckerstorfer, 2015), which in response, individuals and societies made various attempts to reduce loss of life, property and environment damage through innovation and adaptation (Bas Van Bavel, 2020). A similar scenario can be seen from the present times like as the wars, famines, floods, and catastrophic events like as 2004 Indian ocean tsunami, 2005 Kashmir earthquake, 2008 cyclone Nargis, 2010 Haiti Earthquake, 2011 Japan earthquake, 2015 Nepal Earthquake followed by formulation of national and international disaster responses (Coppola, 2015). 
Understanding the importance of disaster and development studies, many researchers have tried to examine the linkages between the two (Fordham M., 2009), (Kapuca, 2014). Various studies have been carried out to include natural, anthropogenic, technological hazards and to study the Influence of geophysical environment on these hazards and their interaction (Baoyin Liu, 2016), (Joel C. Gill, 2014), (Joel C. Gill, 2016). E.g., Earthquake induced secondary hazards like landslides resulting in dammed lakes triggering tertiary hazards (HAN Jinliang, 2007). Most of hazards when treated individually don't focus on domino, cascade or compound effects like in multihazard analysis as evident from various studies (Valentina Gallina, 2015). In developing countries, occurrence of multiple disasters characterized by high rates of poverty, illiteracy, social exclusion and environmental degradation is very common (Barrantes, 2018). The movement towards greater economic development leads to the increase in use of natural resources. The application of new technologies agricultural, construction and transport sectors is greatly endangering air, water and land quality. Similarly, the rapid growth of tourism and pressure exerted by tourist movement on the environment has an impact on a global level (Alberta Tahira, 2020).

In recent years, disasters and development has become a major focus in developed and developing countries (Naim kapucu, 2014). In recent times addressing the challenges of everyday human life, reducing disaster risk, and achieving more sustainable development presents a common agenda(Fordham M., 2007). Thus, multi oriented study focuses on multiple risks that form the basis for risk reduction and sustainable development in a region (Melanie Kappes \& Glade, 2010). These studies address the various stages of disaster management i.e. vulnerability, risk assessment, management including prevention, mitigation, preparedness, response and recovery (UN 2002). Integrated analysis inspite of challenges has been encouraged in global framework like the Hyogo Framework of Action (HFA) and Sendai Framework for Disaster Risk Reduction (SFDRR) (Melanie S. kappes, 2012). There is a continuous focus to include more hazards interactions at present to include as many hazards as possible. Thus a close relationship between different risks and cascade effects stresses for a more integrated approach to be applied at different levels (Serkan Girgin, 2019).

The present study is based on Union Territory (UT) of Ladakh (34.00N, 78.00E) of North-Western Himalayas (Figure 1.1). The region is known for having its own peculiar charm, cultural harmony, different ethnic identity, and complex topography. In geographical terms, the whole region is divided into three major sub regions known as Upper Ladakh, Central and Lower Ladakh (Dar, 2017). The region has been attracting people to explore it from very ancient times (F.M. hassnain, 2012). The region on one side was known for its glorious history of having its own kingdom and charm, while on the other side, it also has been continuously affected by wars, natural disasters, climatic extremes (Parvez, 2012), (Masson, 2013). The region because of its extreme location to north coupled with high altitude experiences the most difficult and harsh winters. The region remains cut off from the rest of world due to closure of Zojila pass (connecting road to other states and regions ) from November -May every year due to heavy snowfall and extreme weather conditions. The region because of mountainous nature and complex topography and geomorphology makes it prone to multiple Disasters like earthquakes, floods, landslides, wind/ snow storms, snow avalanches, lightning, hailstorms etc (DM Plan Leh and kargil). The region has witnessed many disasters in the past like the cloud burst induced flashfloods of 2010 and there has been considerable increase in the frequency of other natural hazards because of population growth, climate change and growth of new settlements in unsafe locations around unstable slopes (Suri, 2018), (Barrett, 2014).

Owing to its sparse population and remote location, the region had received limited attention of policy makers and largely remained off the radar of environmental planners till the end of the 20th century. As the region lies in close proximity to the international border with Pakistan and China, it has witnessed several minor to major

Page $3 / 21$ 
conflicts in the past and large military presence makes it a potential future conflict region (peter sammonds, 2019). Similarly, the development pace of the region has gone through different phases owing to difficult geomorphology, extreme weather and isolated location in many sectors. The tourism sector has played an important role in developmental transformation of the region. This development has been affected by both disaster and developmental events. Growth of the tourism sector is believed to be complex and nonlinear phenomenon depending on several factors like uprisings, conflict, economic slowdowns, global capital flows, tourist habits, new trend destinations, weather and climate changes and recent natural disasters etc (Peliciardi, 2016). All these factors are not under the local control and can occur at unpredictable pace and time, thus, resulting in fluctuations in annual tourist inflow to the region. Since the opening of tourism sector in 1974, the region has witnessed a continuous increase with occasional dramatic fall in the tourist flow and related activities in the region (Vladimiro, 2013), (Pelliciardi, 2010).

Considering the complex nature of the region, this study has been carried out with an aim to understand the linkages between disasters, development and vulnerability. There has been studies having ample evidences, of linkages between disaster, development and vulnerability (Fordham M., 2009). These studies emphasis for a close coordination within these sectors that it remains viable over an indefinite period and does not degrade or alter the environment and other vulnerabilities to such an extent that it impacts the successful development and wellbeing of other activities and processes (Desbiolles, 2017). The present study focuses on a similar interface analysis in the region. For the analysis, tourism sector of the region has been taken as principal developmental criterion which has been studied under disaster and development scenarios. The role of disasters, development and emerging vulnerabilities are studied for a long-term effective planning through appropriate mitigation strategies for sustainable development.

\section{Study Area}

The study has been carried out in the Union Territory of Ladakh which is one of the remotest and largest UTs in terms of area in India. It is also known as a "Cold Desert", "Moon Land" due to its extreme climatic conditions and barren topography (Gompertz, 2000). The region as shown in shares borders with countries like china in the North and the East and Pakistan and Afghanistan in the west and North West. It lies amidst the world's highest mountain ranges, at an elevation of 11,000 feet, the Karakorum and Hindu-Kush to the North, the Indian Himalayas to the South and the vast Tibetan Plateau in the East (Figure 1.1). On account of high altitude extreme location to north, the region experiences the most difficult and harsh winters. Due to heavy snowfall the entire region remains cut off from the rest of world due to closure of Zojila and Manali passes (connecting roads to other states and regions) from November -May every year. The Ladakh region is divided into Leh and Kargil districts with a population of around 3 lakhs covering an area cover of around 59,196 sq.km (District Disaster Management Plan kargil, 2017-18).

The region because of mountainous nature and complex topography is prone to multiple hazards like earthquakes, floods, landslides, wind/ snow storms, snow avalanches, lightning, hailstorms, wars, etc (DM Plan Leh and kargil-2011). The region has faced the deadliest experience of cloud burst induced flashfloods of 2010(Preeti Gupta, 2015) and many more local level hazards every year like flash floods, landslides, snow avalanches on account of ensuing global warming and prevailing climate change in the recent times.

\section{Methodology}


Present study is based on primary as well as secondary data. For secondary data, various sources including journal articles, reports, books, research reports and government records and remote sensing based data has been used to understand the interface of disasters and development and vulnerability in the region. Secondary data is supplemented with primary data collected through field survey and interviews. Two sample areas from each district were chosen for primary surveys, Leh Town $(34.15 \mathrm{~N}, 77.57 \mathrm{E})$ and Nubra Valley $(34.68 \mathrm{~N}, 77.56 \mathrm{E})$ in Leh district and Kargil Town (34.55N, 76.13E) and Drass town (34.42N, 75.74E) from Kargil district. The target participants were important stakeholders, district officials, guest house owners and local residents. The field survey and interviews focused on understanding emerging vulnerabilities in the region which were analyzed and calculated based on analytical hierarchal process (AHP) method). AHP is a multi-criterion decision making technique introduced by Saaty (1977) which allows subjective as well as objective factors to be considered in decision making(Rohan Kumar, 2016) AHP breaks complex problems into number of factors and alternatives by following a number of steps as explained in detail by (Romulus Costache, 2020). One of the most important steps is to check the Consistency Ratio (CR) to check the quality of pairwise comparisons of the weights assigned and scale of preference as indicated in (Table 1.1). CR for the weights assigned is calculated using the equation, $\boldsymbol{C I}=\boldsymbol{\lambda}-\boldsymbol{n} / \boldsymbol{n}-1$, where $\boldsymbol{\lambda}$ is the largest eigenvalue of pair-wise comparison matrix and $\mathrm{Cl}$ is the consistency index. The consistency ratio (CR) is calculated with the help of equation $\boldsymbol{C R}=\frac{\boldsymbol{C I}}{\boldsymbol{R} \boldsymbol{I}}$, where RI is the random consistency index identified and assigned values by Saaty 1980, 2000 shown in (table 1.2). The consistent comparison is accepted if the $\mathrm{CR}$ value comes less than 0.1 . If it exceeds, the matrix table is reconsidered until it gets less than 0.1

Table 1.1

Scale of preference of factors ( (Saaty, 1977, 2001),

\begin{tabular}{|lll|}
\hline Intensity & $\begin{array}{l}\text { Degree of } \\
\text { preference }\end{array}$ & Explanations \\
\hline 1 & Equally & Factors contribute equally to the objective \\
\hline 5 & Moderately & One factor moderately favour over another \\
\hline 7 & Strongly & Experience and judgment strongly favor one factor over another \\
\hline $2,4,6,8$ & Very strongly & One factor strongly favored over another \\
\hline Reciprocals & Optremely & $\begin{array}{l}\text { The evidence one factor favoring over another is of the highest degree } \\
\text { possible }\end{array}$ \\
\hline
\end{tabular}

Table1.2: Random inconsistency indices (RI) for $n=1,2$... 12 ( (Saaty, 1977, 2001)

\begin{tabular}{|lllllllllllll|}
\hline $\mathbf{N}$ & $\mathbf{1}$ & $\mathbf{2}$ & $\mathbf{3}$ & $\mathbf{4}$ & $\mathbf{5}$ & $\mathbf{6}$ & $\mathbf{7}$ & $\mathbf{8}$ & $\mathbf{9}$ & $\mathbf{1 0}$ & $\mathbf{1 1}$ & $\mathbf{1 2}$ \\
$\mathrm{RI}$ & 0.00 & 0.00 & 0.58 & 0.90 & 1.12 & 1.24 & 1.32 & 1.41 & 1.45 & 1.49 & 1.52 & 1.54 \\
\hline
\end{tabular}




\section{Results And Discussion}

The Ladakh Region with Rugged Terrain and complex topography is prone to multiple hazards. The Region is characterized by extreme climate, rugged topography and sparse population composed of ethnic communities having unique and indigenous culture (Gompertz, 2000). In addition to their physical distinction, the region has a religious and political peculiarity. The Upper and Central Ladakh have a majority of Buddhist population whereas the Lower Ladakh is inhabited by Muslims (Dar, 2017). Ladakh is a multi-hazard prone region which is highly vulnerable to seismic hazards, landslides, snow- avalanches, flash-floods and cloud bursts etc. Besides, anthropogenic hazards like border conflicts and political turmoil in neighboring region of Kashmir has resulted in huge loss of life and property. Analysis of data reveals that series of events took place in the region during the last few decades. In the present study an attempt has been made to study the inter-connection of disasters and developmental events especially the impact of disastrous events on tourism which is emerging as the new economic lifeline of Ladakh region. The study reveals that the region has witnessed many disastrous/crises situations over the years as shown in table (Table1.3) which have caused loss of life and property along with damage to the environment. 
Table 1.3

List of some major Disaster \& Development events in Ladakh region

(Source: Compiled from primary and secondary sources)

\begin{tabular}{|c|c|c|c|c|}
\hline S.No & $\begin{array}{l}\text { Major } \\
\text { Disaster/ } \\
\text { crises } \\
\text { events }\end{array}$ & Year & Description & Reference \\
\hline 01 & $\begin{array}{l}\text { India- } \\
\text { China war }\end{array}$ & 1962 & $\begin{array}{l}\text { India was formally attacked by china. India lost sizable } \\
\text { territory and also suffered large number of causalities due } \\
\text { to Chinese aggression. Huge loss of life was repotted. } \\
\text { However proper construction of Srinagar-Leh National } \\
\text { highway followed } 1962 \text { war. }\end{array}$ & $\begin{array}{l}\text { (Dewan, } \\
\text { 2004) } \\
\text { (Gompertz, } \\
2000)\end{array}$ \\
\hline 02. & $\begin{array}{l}\text { India- } \\
\text { Pakistan } \\
\text { war }\end{array}$ & 1971 & $\begin{array}{l}\text { The } 1971 \text { war, also known as battle of Turtuk, Turtuk and } \\
\text { adjoining areas were captured by India. Loss of life and } \\
\text { separation of families and relatives resulted on either side } \\
\text { of border. }\end{array}$ & $\begin{array}{l}\text { (Gompertz, } \\
\text { 2000) }\end{array}$ \\
\hline 03. & $\begin{array}{l}\text { Political } \\
\text { turmoil } \\
\text { and } \\
\text { militancy } \\
\text { in } \\
\text { Kashmir }\end{array}$ & $\begin{array}{l}1989 \\
\text { onwards }\end{array}$ & $\begin{array}{l}\text { Political turmoil and militancy resulted in huge loss in } \\
\text { every sector especially tourism industry of whole region. } \\
\text { Ladakh also got considerably affected because of only } \\
\text { feasible and preferred road connectivity along Srinagar- } \\
\text { Leh national highway. }\end{array}$ & $\begin{array}{l}\text { (Dewan, } \\
\text { 2004) }\end{array}$ \\
\hline 04. & $\begin{array}{l}\text { India } \\
\text { Pakistan } \\
\text { war. }\end{array}$ & 1999 & $\begin{array}{l}\text { The } 1999 \text { war also known as kargil war was fought at a } \\
\text { stretch of nearly } 160 \mathrm{~km} \text { for } 74 \text { days (May-July,). The war } \\
\text { caused a huge loss of life and property on both sides. India } \\
\text { today estimated the war cost India } 1110 \text { crore. However it } \\
\text { also generated vide publicity and media attention; boosting } \\
\text { tourism in the subsequent years }\end{array}$ & $\begin{array}{l}\text { (Dewan, } \\
2004)\end{array}$ \\
\hline 05. & $\begin{array}{l}\text { LOC } \\
\text { kargil } \\
\text { movie, } \\
\text { 3idiot } \\
\text { movie }\end{array}$ & $\begin{array}{l}2004 \\
2009\end{array}$ & $\begin{array}{l}\text { These movies helped to showcase the region positively } \\
\text { and helped in tremendous domestic tourist's growth in } \\
\text { subsequent years. }\end{array}$ & $\begin{array}{l}\text { From } \\
\text { tourism data } \\
\text { and field } \\
\text { surveys }\end{array}$ \\
\hline 06. & $\begin{array}{l}\text { Leh Cloud } \\
\text { burst/ } \\
\text { Flash } \\
\text { floods. }\end{array}$ & 2010 & $\begin{array}{l}\text { The cloud burst induced flash floods of } 2010 \text { caused one } \\
\text { of the deadliest disasters that resulted in huge loss of life } \\
\text { and property in Leh Ladakh. A total of } 71 \text { villages and } \\
\text { around } 9000 \text { people got affected from it. } 234 \text { persons lost } \\
\text { their lives and over } 800 \text { were reported missing. }\end{array}$ & $\begin{array}{l}\text { (Disaster } \\
\text { Management } \\
\text { Plan Leh } \\
\text { District, } \\
2011-12 \text { ) } \\
\text { (preeti Gupta, } \\
\text { 2012), }\end{array}$ \\
\hline 07. & $\begin{array}{l}\text { Removal } \\
\text { of special } \\
\text { status } \\
\text { and } \\
\text { formation } \\
\text { of UT } \\
\text { Ladakh. }\end{array}$ & 2019 & $\begin{array}{l}\text { There is division of views among people some favoring it } \\
\text { as a developmental step while others feel like it will } \\
\text { demage the culture, environment and may also trigger } \\
\text { violent border clashes. The tourism of the region has faced } \\
\text { a huge loss in the year 2019-2020 }\end{array}$ & $\begin{array}{l}\text { Field survey } \\
\text { and } \\
\text { interviews }\end{array}$ \\
\hline
\end{tabular}




\begin{tabular}{|lllll|}
\hline S.No & $\begin{array}{l}\text { Major } \\
\text { Disaster/ } \\
\text { crises } \\
\text { events }\end{array}$ & Year & Description & Reference \\
\hline 08. & $\begin{array}{l}\text { COVID_19 } \\
\text { Pandemic }\end{array}$ & Ongoing & $\begin{array}{l}\text { Ladakh region because of extreme winter has been the } \\
\text { worst suffers of the pandemic. It resulted in huge loss to } \\
\text { tourism and economy of the region like as in many other } \\
\text { parts of the world. }\end{array}$ & $\begin{array}{l}\text { (Ezekiel J. } \\
\text { Emanuel, } \\
\end{array}$ \\
& & $\begin{array}{l}\text { (Hariri- } \\
\text { Ardebili, } \\
\text { 2020), Field } \\
\text { surveys and } \\
\text { interviews. }\end{array}$ \\
\hline
\end{tabular}

Ladakh region is characterized with arid climate, high altitude, rugged topography, unique culture and sparse population situated in a remote part of India in the trans-Himalayan region. The region earlier acted as a center for trade between South Asian and Central Asian countries and many travelers used to visits the place for trade and travels. However political instability and decay of central Asian trade route over the period of time adversely affected the economic prospectus of the region. After the independence of India, it became a part of Jammu and Kashmir State and by virtue of being on the border of China and Pakistan the entry was largely restricted by strict permit regime which hampered the tourist flow to this region.

Ladakh being arid cold desert has little prospectus for the development of agriculture due various constraints and consequently only subsistence agriculture is practiced in certain pockets which is marked by low yield and fluctuating returns. Besides pastoral farming is also practiced by various groups for sustenance which too has got its own limitations. Therefore the growth of tourism in this region has opened new avenues and has played a vital role in economic transformation of the region. In the present study as shown in flow-chart (Figure1.2), an attempt has been made to study the interrelationship of disasters and developmental processes by highlighting the positive and negative effects of natural and man-induced disasters on the Ladakh with special reference to tourism which is emerging as the new economic lifeline in this remote Trans-Himalayan Region.

Although the disasters faced by Ladakh have many adverse implications but a deeper analysis reveals that they have actually benefitted the region in many ways as they helped in boosting the basic infrastructure, transportation and communication, media coverage and publicity; which was helpful in showcasing the immense tourism potential in Ladakh. The tourist flow patterns post these disasters confirm the notion that thought disasters caused an immediate dip in tourist arrivals but in the long run were beneficial in attracting large number of tourists to the region. These disasters also managed to put Ladakh on the radar of policy makers and planners on account of its tremendous geo-strategic importance as it is a sensitive border and a potential conflict zone. Figure 1.3 clearly reflects the spurt in tourist arrivals in Ladakh after major disastrous events on account of widespread media coverage and publicity.

a) Permit Relaxation for Tourists in Ladakh: There are evidences from literature but no actual figures exist till 1974 when tourism got formally opened for the tourists (Aabedi, 2015). Since then, the tourism industry has provided a great contribution for economic and social development of the region (Dewan, 2004) (Gompertz, 2000). Construction of national highways after 1962 and airport in 1985 improved the connectivity in this remote region. From 1974 onwards tourism industry of the region has greatly contributed for the economic and social development of the region (Dewan, 2004) (Gompertz, 2000). The economy of the region over the period of time 
became more and more dependent on the tourism industry and consequently, prone to fluctuations induced by various disasters in and around the region. From the (figure 1.3) it becomes evident that Ladakh has witnessed a modest and steady growth in tourist arrivals after it was formally thrown open in 1974 for tourists till the outbreak of insurgency in Jammu and Kashmir State in 1989. Ladakh tourism also received a boost by the augmentation and up-gradation of aviation infrastructure in the region during the last quarter of 20th century. The tourist flow in Ladakh registered a compound annual growth rate (CAGR) of 5.37\% from 1980-1989.

b) Insurgency \&Political Turmoil in Jammu and Kashmir (1990 onwards): It had its severe implications on the tourism of whole region including Ladakh. Tourist arrivals declined significantly as most the European countries along with the USA and Canada issued advisories to the tourists to avoid the region as many tourist were abducted and subsequently killed by armed groups operating in this State in which according to conservative official estimates more than 50000 people lost their lives. Despite that fact that Ladakh region was largely free of insurgency but the only feasible highway connecting the region with the rest of India and world was going through the Valley of Kashmir which was highly disturbed area. The tourist arrivals declined and the region witnessed a substantial decline in the tourist arrivals which is evident from (figure 1.3).

c) 1999-War: also known as Kargil war resulted in the considerable loss of life and property as descried in (Table 1.1). The war although ended after 74 days but cease fire violations continued till 2002. According to reports few thousand soldiers were lost on both sides of the border, thousands of people were temporarily displaced and war incurred huge financial burden on both the countries involved. It can be considered a worst event followed by many positive developments in the region. It attracted widespread media coverage and publicity in which unique topography, pristine nature and potential for adventure tourism were highlighted. Majority of the high potential areas of the region came to limelight only after this war. Tiger hill, Tolling, Drass valley, war memorial became household names in India. Kargil war also grabbed the attention of Indian cinema which resulted in the making of Movies like LOC Kargil and later on 3 idiots which resulted in spurt in tourist arrivals in the first decade of 21st century. The shooting of 3 idiot movie in Ladakh (2009), had put the region in the limelight at national as well as at international forums. The new trend which emerged due to publicity post Kargil war was the phenomenal increase in the domestic tourist in the Ladakh region for the first time. The compound annual growth rate of tourist arrival from 2000 to 2010 was $19.21 \%$

d) 2010-2018 (Phase of rapid tourism expansion): This phase described as the most crucial phases in the tourism industry of the region. The cloud burst incident of 2010 also drew attention of researchers and policy makers to this highly vulnerable and remote region of the country. Although Ladakh suffered 234 casualties and nearly 800 people were reported missing besides incurring huge economic losses, the cloud burst received tremendous media coverage on national and international level which is believed to be one the causes of surge in tourist arrivals in the subsequent years breaking all past records. A total of 22, 57, 283 tourists (foreign 3, 75,018 and domestic $18,82,265$ ) visited Ladakh during this time period as witnessed in the (figure 1.1). The CAGR of tourist flow post 2010 cloud burst till 2018 is impressive at $19.29 \%$.

\section{e) 2019-2020 (Abrogation of Special Status in 2019 and subsequent Covid Pandemic1n 2020 onwards): The} removal of article 370 and decision of formulation of separate UT of Jammu and Kashmir and UT of Ladakh on August 5 of 2019 has deserted the region all of the sudden from domestic and foreign tourists. A decline has been witnessed in 2019 compared to previous years. This followed covid-19 pendemic in year 2020 which resulted in more drastic fall in the tourism flow in the region like as in other parts of the world (Alberta Tahira, 2020). Moreover, the ongoing conflict between India and china border would have also influenced the tourist flow during the later months of 2020 (Pelliciardi Vladimiro, 2021). 
From the analysis of disaster development interface events, it appears that disasters helped in long term tourism development with occasional unpredictable setbacks. Tourism growth gets influenced by many factors like language, transportation, communication, culture, religion, comfort, region, etc (Pelliciardi, 2010). But, bloom of tourism in this fragile region has been because of disaster induced developmental opportunities. Thus on one side tourism industry proved to be a great developmental driver for the region but on the other side, it is showing new associated vulnerabilities. The bloom in tourism sector of Ladakh post 1999 kargil conflict is largely attributed to spurt in the domestic tourist arrival in many ways which has promoted unplanned growth in tourism industry and related infrastructural developments. This has increased related vulnerabilities in this fragile region which is highly susceptible to unplanned developments. This can result in long term negative impacts if not managed properly (Pelliciardi, 2010). It's thus important to link the development with the geophysical environment for a better and well planned growth in every developmental sector.

In this section, an attempt has been made to understand, how tourism development and regional geo-physical factors has influenced the vulnerability scenario. Vulnerability as a dynamic phenomenon is known to be highly influenced by combination of physical, social, economic, and geo physical factors. These factors can either decrease or increase vulnerability because of human actions (Coppola, 2015). It varies temporally because of people moving through different life stages with varying mixes of resources and liabilities. The region has faced a lot of challenges in terms of natural and anthropogenic disasters which influenced environmental, social, climate change, border conflicts induced vulnerabilities in this geo fragile region. These combined challenges further increase apprehensions for a region if appropriate strategies are not adopted (Birkmann, 2006). In order to understand and analyze the emerging vulnerability and related concerns in detail, multi criteria approach as explained in detail in methodological section has been adopted. The vulnerability is studied by identifying the general vulnerability using main indicators followed by sub- indictors as described below in table (1.4 \& 1.5). Remote sensing based geo physical analysis has been employed to get a comprehensive linkage between development and future scenario planning in this highly fragile region.

Table 1.4

Pair-wise comparison of main indicators, normalized weights and consistency ratio

\begin{tabular}{|c|c|c|c|c|c|c|}
\hline $\begin{array}{l}\text { Main } \\
\text { Indicators }\end{array}$ & $\begin{array}{l}\text { Physical } \\
\text { vulnerability }\end{array}$ & $\begin{array}{l}\text { Economic } \\
\text { vulnerability }\end{array}$ & $\begin{array}{l}\text { Environmental } \\
\text { vulnerability }\end{array}$ & $\begin{array}{l}\text { Socio } \\
\text { cultural } \\
\text { vulnerability }\end{array}$ & $\begin{array}{l}\text { Climate } \\
\text { change } \\
\text { vulnerability }\end{array}$ & $\begin{array}{l}\text { Normalized } \\
\text { Weights }\end{array}$ \\
\hline $\begin{array}{l}\text { Physical } \\
\text { vulnerability }\end{array}$ & 1 & & & & & 0.07 \\
\hline $\begin{array}{l}\text { Economic } \\
\text { vulnerability }\end{array}$ & 2 & 1 & & & & 0.12 \\
\hline $\begin{array}{l}\text { Environmental } \\
\text { vulnerability }\end{array}$ & 3 & 2 & 1 & & & 0.16 \\
\hline $\begin{array}{l}\text { Socio cultural } \\
\text { vulnerability }\end{array}$ & 4 & 3 & 3 & 1 & & 0.29 \\
\hline $\begin{array}{l}\text { Climate } \\
\text { change } \\
\text { vulnerability }\end{array}$ & 4 & 2 & 3 & 2 & 1 & 0.36 \\
\hline $\mathrm{Cl}$ & 0.07 & $(\lambda \max )$ & 5.28 & & CR & 0.06 \\
\hline
\end{tabular}


Page $11 / 21$ 
Table 1.5

Pair-wise comparison of Sub- indicators, normalized weights and consistency ratio

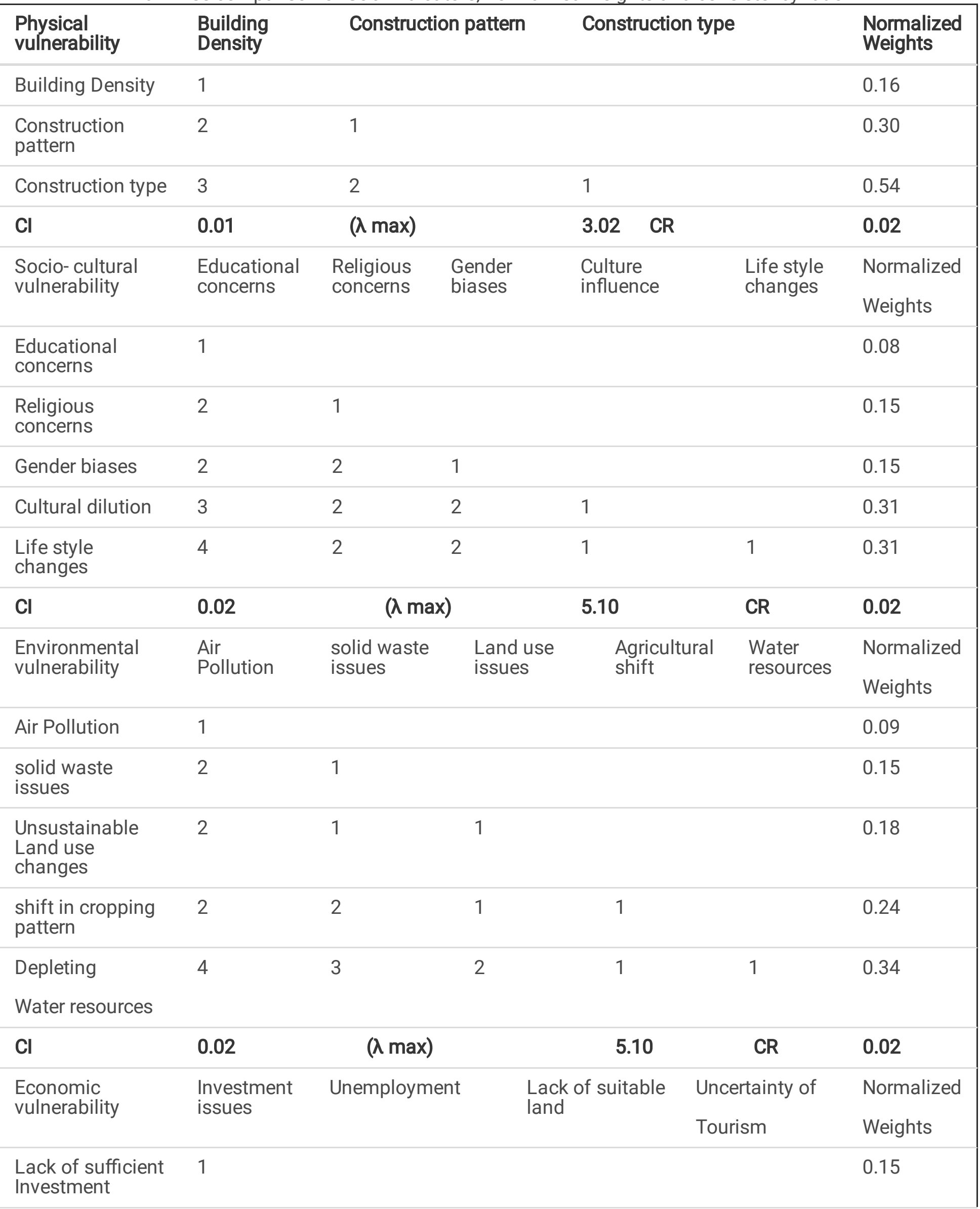




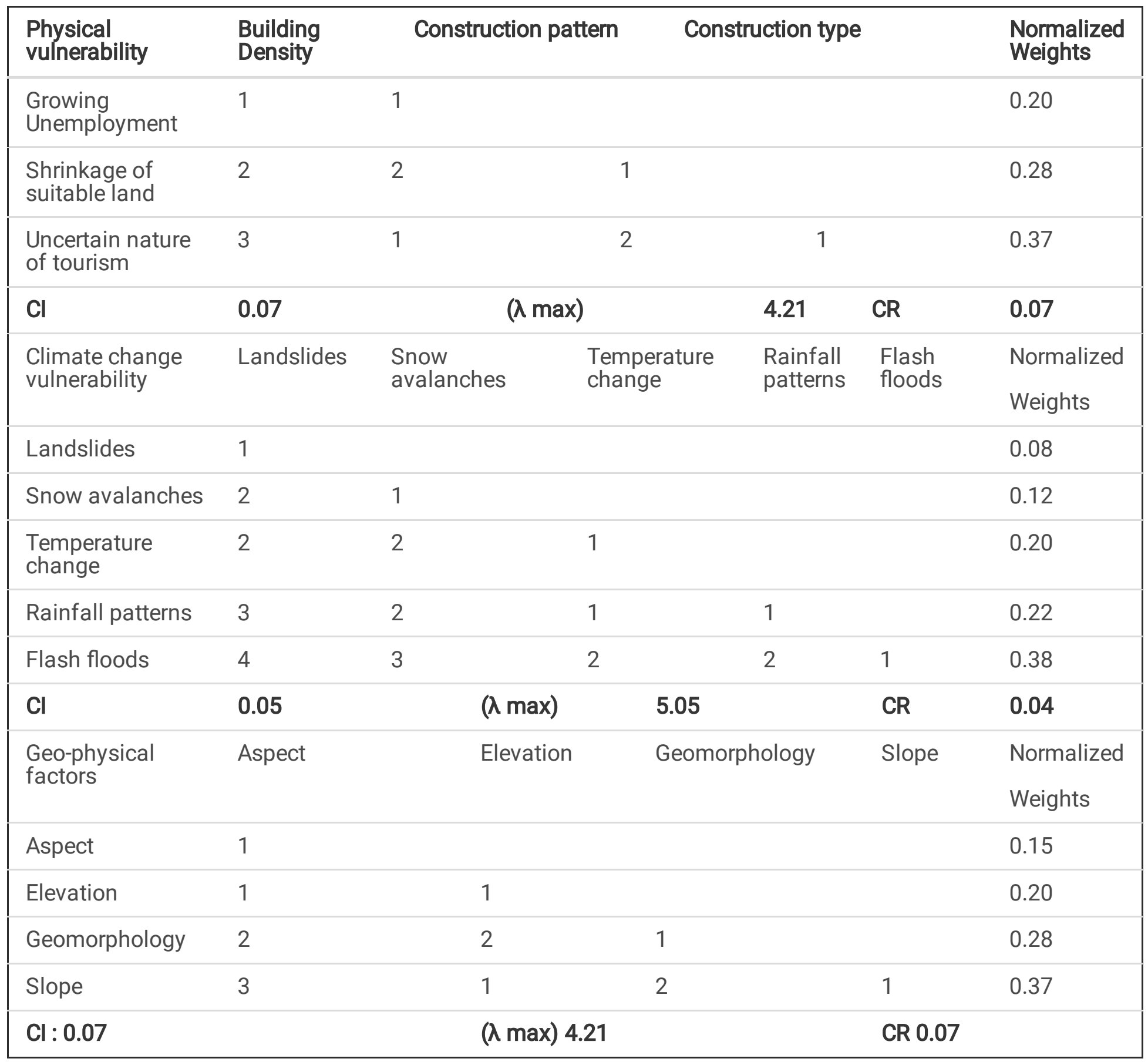

\section{Climate Change Vulnerability:}

Climate change is a major concern for the region and it needs a more detailed study to understand its implications. The changing climate pattern and associated vulnerabilities have also been reported by many others researchers after the 2010 cloud burst disaster. A lot of local level hydrometerological incidents have been reported during the recent years. The survey on the people's perception reveals that the region is also witnessing a change in rainfall and temperature patterns and associated hazards like flash floods (Image 1), cloud bursts \& landslides as evident from (Table 1.5).

Socio - Cultural Vulnerability: 
The study reveals that huge influx of tourist in the region has increased socio-cultural vulnerability with its profound impact on the life style across the region. The present generation is getting more attracted to smoking and alcohol with every passing day owing to large scale exposure through tourism (Image 2). A transformation has been witnessed in traditional way of food, clothing, marriage ceremonies etc. People perceive that the changing life style has impacted the religious practices among the youth who are vulnerable to religious conversions which have already been reported from some parts of Leh district. Gender bias is evident as boys get more opportunities compared to girls in the emerging tourism based job market of the region due to which females are having a limited role in decision making processes. Life style changes, Cultural dilution and gender bias are the three main factors enhancing socio-cultural vulnerability in the region which is evident from Table 1.5 .

\section{Environmental vulnerability:}

The study reveals that the reason for increasing environmental vulnerabilities of the region may be attributed to socio-economic transformation, greater influx of tourists and changing climate over the period of time. From various studies, decrease in underground water level is evident from the extinction of many natural springs and glaciers in the region (Image 3). The socio-economic transformation has resulted in higher daily consumption of water. In almost every new construction, continuous water supply is maintained during summers and use of washing machines, replacement of traditional pit system toilets by flash system and high water dependent cement building constructions resulted in high demand for water. According to primary survey around 3000 plastic bottles are collected from Nubra valley on daily basis during tourist season. The solid waste generated during the tourist season gets less attention along desolate roads and in many far-off locations like Hunder, Pangong Tso, Turtuk, and Panamik thereby increasing water, soil and air pollution related concerns. It has been observed that depleting water resources, Changing cropping pattern and unsustainable landuse changes in the area are perceived as important factors that enhance the environmental vulnerability in the region which is evident from Table 1.5.

\section{Economic Vulnerability:}

The economic scenario of the region has always been unpredictable. Despite tremendous growth in the tourist inflow and enhanced economic growth, there is always uncertainty in this sector. People have seen such phases in the past and recent times. Recent events like the abrogation of Article 370, Corona Virus pandemic have negatively impacted the tourist flow in the region. These uncertain events increase the economic vulnerability of the people who had already invested heavily in anticipation good returns. In addition, shrinkage of suitable land which is very scarce (rugged terrain) on account of unplanned and haphazard growth promoted by spurt in tourism has also increased the economic vulnerability in the region. Besides, close proximity to borders and political conflict in the area enhances the uncertainty of tourism the main growth engine in the region, which has a considerable impact of the economic wellbeing of the region. People are of the opinion that these investments are also susceptible to losses from sudden extreme events like wars, earthquakes, flash floods etc. The study also indicates, that uncertain nature of tourism amid the high susceptibility to various natural and manmade disasters coupled with lack other avenues in the region has resulted high unemployment rate which is considered as an important factor in growing economic vulnerability in the fragile region as evident from Table 1.5.

\section{Physical Vulnerability:}


The physical vulnerability of the region is strongly influenced by geomorphology and topography of the region as shown in maps. Increase in new settlements due to population growth and tourism industry has resulted in haphazard construction along unstable slopes (Image 4) without following specific building codes and proper engineering techniques. The study reveals that there is an obvious shift in construction patterns and construction type in the region. Traditional construction pattern is slowly giving way to modern construction styles which are lacking compatibility with the delicate geo-environmental framework of the region (Table 1.5). As per the local perceptions, new construction patterns need extra heating arrangements to combat extreme weather as compared to traditional ones and are highly energy dependent and less cost effective. The newly constructed RCC buildings with large windows and tin roofs are material dependent from other states, increasing the cost of constructions. During winters, the spontaneous snow melt and fall from tin roof construction occupies more surface area compared to traditional constructions which results in disputes between neighbours thus creating tension and disharmony among otherwise peaceful residents. New construction styles require more space and thus promote wastage of precocious land in the region.

\section{Geophysical factors}

The geophysical factors influence the vulnerability scenario of a region (Joel C. Gill, 2014). The vulnerability scenario of study area is highly influenced by geo physical setup as evident from the following maps as shown in Fig. 1.4. Four geo physical layers have been generated with the help of Remote sensing techniques to understand its role in future development scenario of the region. The Slope has a strong influence in the hazard occurrence and developmental vulnerabilities in a region. Slope layer has been divided into four classes showing a higher percentage of slope pixel count in class second (22-43) followed by class third (44-64), class first (0-21) and class fourth (65-85). Thus, AHP weight for slope (0.37) implies a highest influence as majority of region is highly unstable and susceptible. The geomorphology layer generated for the study area includes more than 30 classes with few having dominance in the region. The highly dissected mountains cover the maximum class area followed by snow and glacier class. AHP employed results (0.28) show the high fragility of the region for developmental aspects. The elevation and aspect layers have similar concerns. Majority of the elevation (in meters) falls in class three (4800-5300), followed by class second (4100-4700), class fourth (5400-74000, and class first (2500-4000). The higher elevation thus strongly influences the climate and extreme weather vulnerabilities. AHP results weight (0.20) has been assigned for elevation layer. Aspect layer classes have a relatively uniform value with flat class having the least pixel count. Thus aspect layer depicts the uncertainty and complex topography of the region. The disaster development interface along with vulnerability scenario discussed here covers both geo physical and anthropogenic parameters which can help in a comprehensive understanding of long term positive development in highly susceptible region of Ladakh. The study focuses on importance to include both the geo physical and anthropogenic parameters in long term development of the region for employing region specific mitigation strategies.

\section{Conclusion}

The Study revealed that the region has gone through both disasters and development phases. From the study, an attempt has been made to understand the linkage between disaster and developmental events along with the vulnerability scenario in the region. A special focus has been given to tourism sector of the region to understand the linkage between disasters and developmental and vulnerability. The results find that the region has been affected positively from these disaster events, which enhanced tourism potential and other developmental 
sectors. The high influx of foreign and domestic tourist coupled with increasing intensity and frequency of various disasters. Factors like political instability in neighboring region Kashmir, 1999 Kargil war, cloud burst, abrogation of article 370, Corona Virus pandemic 2019-20, adversely affected the tourist flow in the region. Disasters provided opportunities for development which in turn makes the region susceptible to increase in physical, social, economic, environmental and climate change related vulnerabilities. The present state of climate change and associated hazards poses greater challenges for the region in terms of hydro- meteorological hazards, glacier retreat, flash floods, water crisis, etc, which needs proper management and in-depth studies to combat the adverse impacts. The findings of the present study validate the rising vulnerabilities in the region emphasizing the need for appropriate mitigation measures and proper integration of disasters and development strategies in long term sustainable growth in every sector. The mitigation strategy should include proper land use laws/ practices involving local level communities and stakeholders. The local participation needs to be strengthened by raising awareness among the masses about the future concerns. The results could be employed for in-depth studies involving multi hazard scenario to frame region specific disaster and development strategies so that a positive relationship gets established between them. This can enable reduce disaster risks and attain sustainable development.

\section{Declarations}

Conflict of interest statement: The authors listed here have no conflict of interests.

Ethical approval: All ethical standards were taken care of during this study.

Consent for publication: This publication is nowhere else under consideration for publication

Code availability: NOT applicable

Availability of data and material: All the data sources are cited and referenced which have been used in this study

Acknowledgment: The third author is highly thankful to Council for Scientific and Industrial Research (CSIR) New Delhi, Govt. of India, for their financial support, which enabled to conduct this study in the remote Himalayan region of India.

\section{References}

1. (2011-12). Disaster Management Plan Leh District. Office of the District Disaster Management Authority Leh.

2. (2017-18). District Disaster Management Plan kargil. Office of the District Disaster Management Authority Kargil.

3. Aabedi, Z.-u.-A. (2015). Ladakh Then And Now. New Delhi: Atlantic Publishers And Distributors.

4. Alberta Tahira, a. e. (2020). sustainable tourism development- analysis of tourism development in Kosovo. ACC journal .

5. Anderson, M. B. (1991). Vulnerability to disasters and sustainable development: A general framework for assessing vulnerability .

6. Baoyin Liu, Y. L. (2016). Hazard interaction analysis for multi-hazard risk assessment: a systematic classification based on hazard forming environment. . Natural Hazards and Earth System Sciences . 
7. Barrett, K. N. (2014). Assessing the Determinants Facilitating Local Vulnerabilities and Adaptive Capacities to Climate Chnage in High Mountain Environments: A Case Study of Northern Ladakh, India.

8. Bas Van Bavel, a. e. (2020). The Vulnerability and Resilience of Past Societies. Cambridge University Press.

9. Birkmann, J. (2006). Measuring Vulnerability to Natural Hazards: Towards Resilient Societies.

10. Collins, A. E. (2018). Advancing the Disaster and Development Paradigm. International Journal Disaster Risk Science.

11. Coppola, D. P. (2015). Introduction to International Disaster Management. London : Elsevier.

12. Desbiolles, F. H. (2017). Sustainable tourism: Sustaining tourism or something more? ELSEVIER.

13. Dewan, P. (2004). Jammu, Kashmir and Ladakh. New Delhi: Manas Publications.

14. Ezekiel J. Emanuel, G. P. (2020). Fair Allocation of Scarce Medical Resources in the Time of Covid-19. The new england journal of medicine.

15. F.M. hassnain, M. O. (2012). LADAKH: THE MOONLAND. Srinagar: Gulshan Books.

16. Fordham, M. (2007). disaster and development research and practise: A necessary eclecticism? In handbook of disaster resesarch. New york: Springer New york.

17. Fordham, M. (2009). Disaster and Developemnt Research and Practise: A Necessary Eclecticism. UK.

18. Gompertz, G. (2000). Magic Ladakh, An Intimate Picture of Land of Topsy-Turvey costumes and Great Natural Beauty. Asian Educational Services.

19. Hariri-Ardebili, M. A. (2020). Living in a Multi-Risk Chaotic Condition: Pandemic, Natural Hazards and Complex Emergencies. International Journal Of Environment Research and Public Health .

20. Kapuca, N. (2014). Disaster and Development: Examining Global Issues and Cases.

21. Kirby, T. (2020). Evidence mounts on the disproportionate effect of COVID-19.

22. Kulatunga, U. (2010). limpact of culture towards Disaster risk reduction. 19(4), 438-451.

23. Manyena, S. (2012). Disaster and development paradigms: Too close for comfort?

24. Masson, V. L. (2013). Exploring Disaster Risk Reduction and Climate Change Adaptation from a gender perspective Insights from Ladakh, India.

25. Naim kapucu, K. T. (2014). Disaster and Development: Investigating an integrated Framework. switzerland.

26. Parvez, D. (2012). Amazing Ladakh Travel, trekking, religion, culture, wildlife,. New Delhi: Manas Publications.

27. Peliciardi, V. (2016). Recent trends in tourist arrivals in Leh district.

28. Pelliciardi, V. (2010). Tourism traffic volumes in Leh district: an overview.

29. peter sammonds, G. B. (2019). Disaster Scenario Simulation of the 2010 cloudburst in Leh, Ladakh. International Journal of Disaster Risk Reduction.

30. preeti Gupta, A. K. (2012, june 25). Disaster Management in Flash Floods in leh( Ladakh): A case study. indian Journal of Community Medicine, 185-188.

31. Preeti Gupta, A. K. (2015). Disaster Management in Flash Floods in Leh (Ladakh): A Case Study.

32. Rajinder Parshad, a. e. (2017). Snow Avalanche Susceptibility Mapping using Remote Sensing and GIS in Nubra-Shyok Basin, Himalaya, India. Indian Journal of Science and Tecnology.

33. Rohan Kumar, R. A. (2016). Landslide Susceptibility Mapping Using Analytical Hierarchy Process (AHP) in Tehri Reservoir Rim Region, Uttarakhand. Journal Geological Society of India. 
34. Romulus Costache, D. T. (2020). identification of areas prone to flash- flood phenomena using multiple criteria decision -making , bivariate statistics, machine learning and their ensembles. science of the total environment.

35. Sati, V. P. (2011). Climate Disasters in the Himalaya: Risk and Vulnerability .

36. Suri, K. (2018). Understanding historical, cultural and religious frameworks of mountain communities and disasters in Nubra valley of Ladakh. International Journal of Disaster Risk Reduction, 1-2.

37. UNDP. ( 2011). United Nations Development Programme. New York.

38. Vladimiro, P. (2013). Estimating total receipts for 2011 from Tourism in Leh District.

\section{Figures}

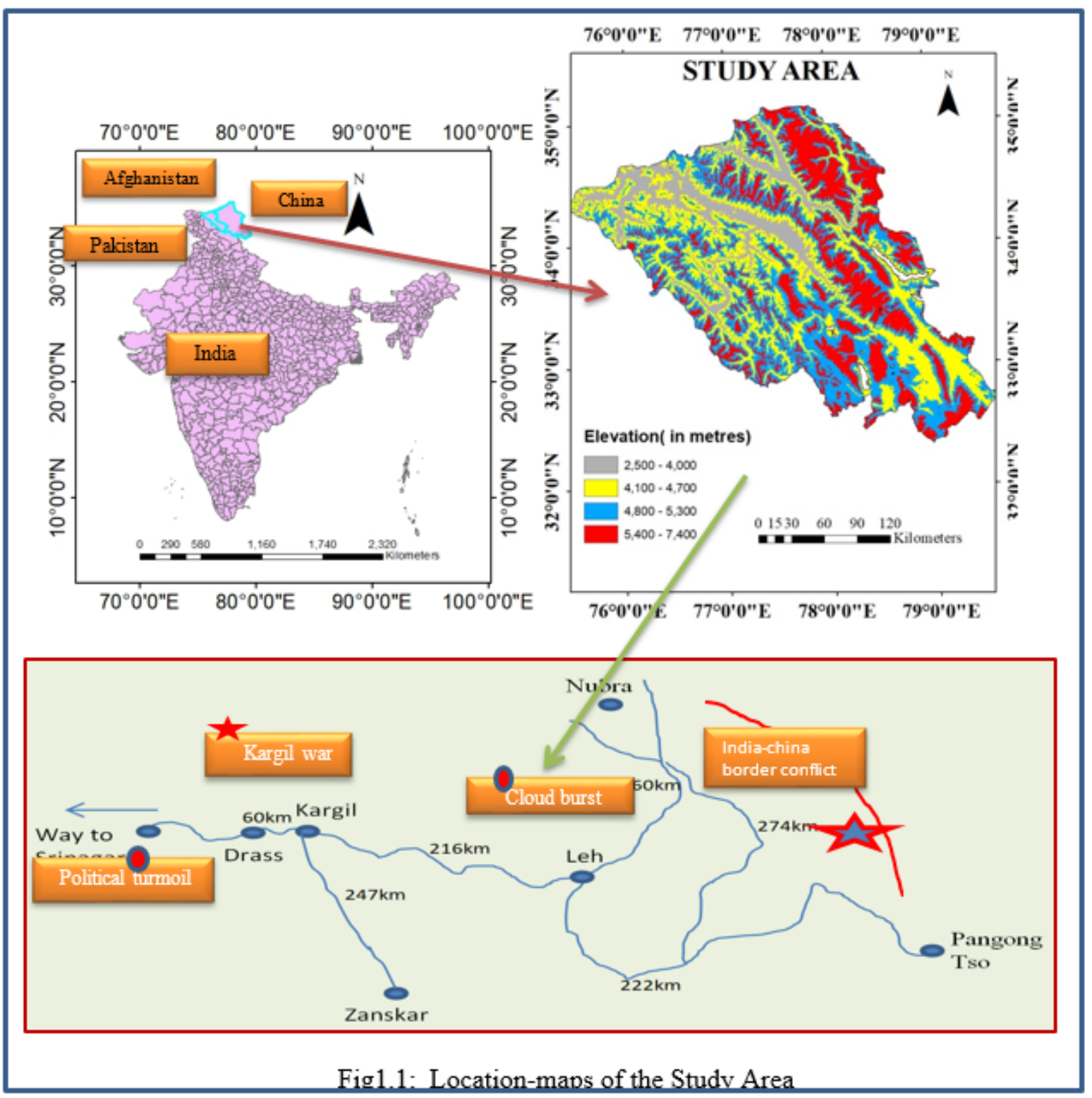

\section{Figure 1}

See image above for figure legend 


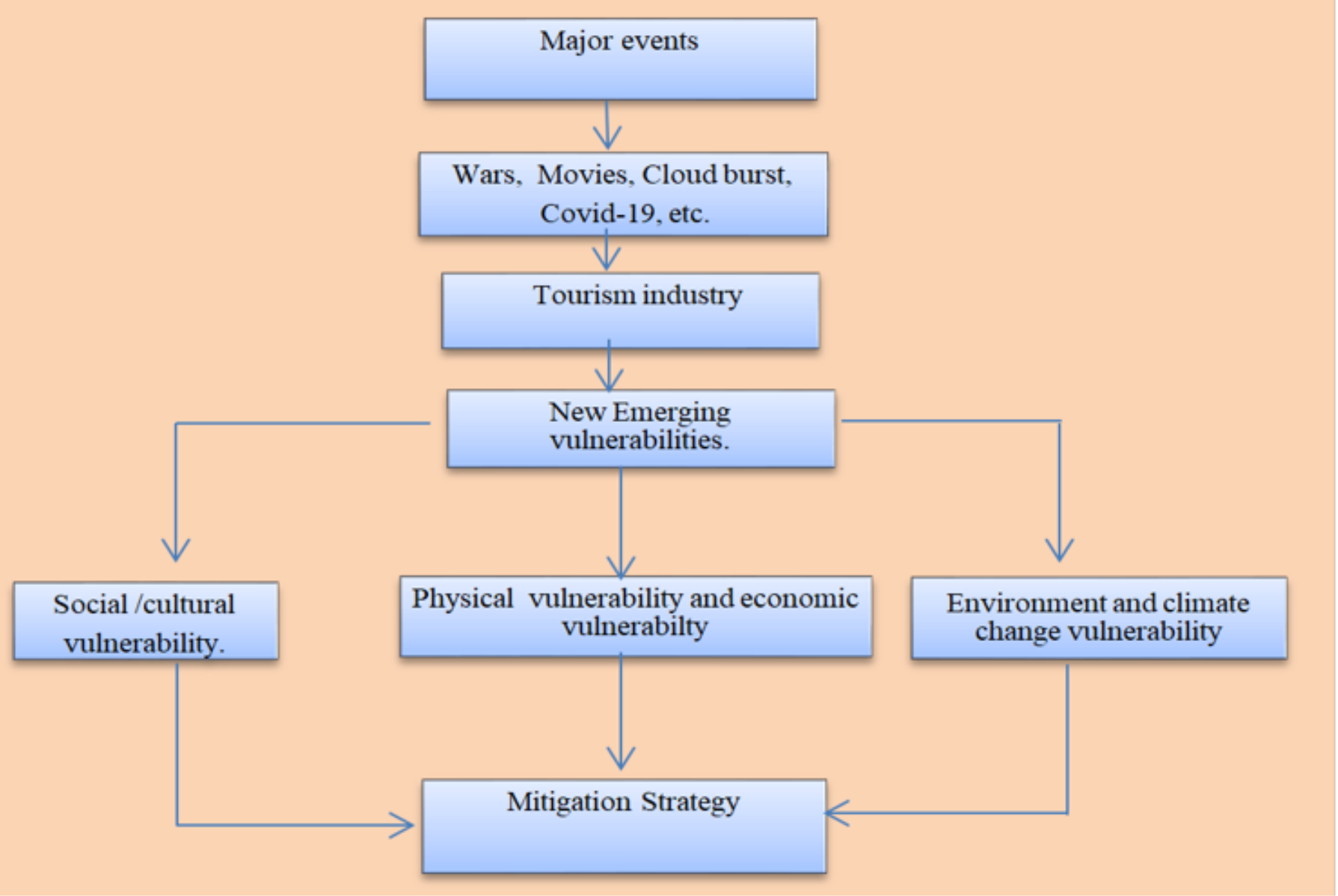

Figure 2

See image above for figure legend

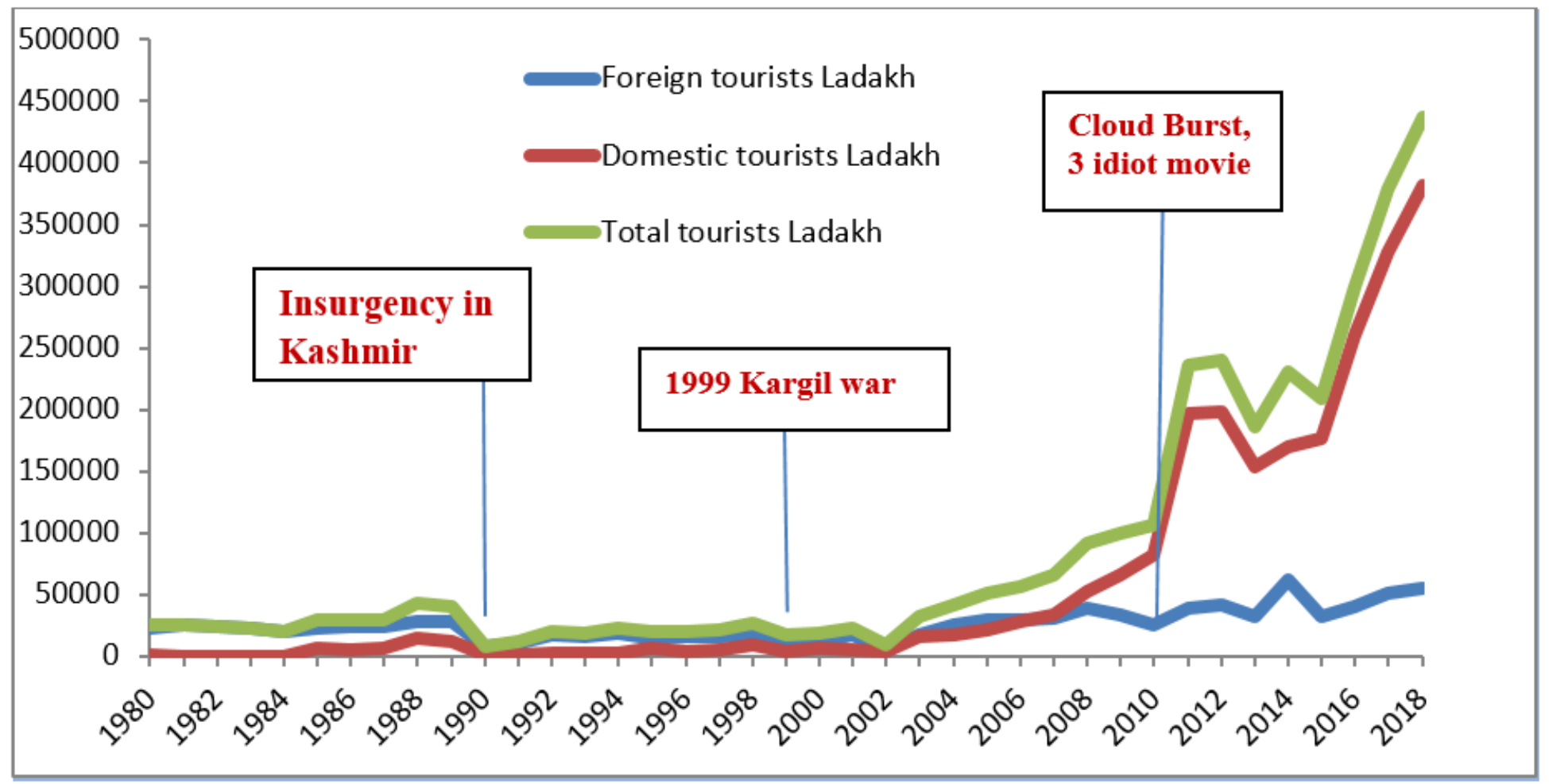


Figure 3

See image above for figure legend

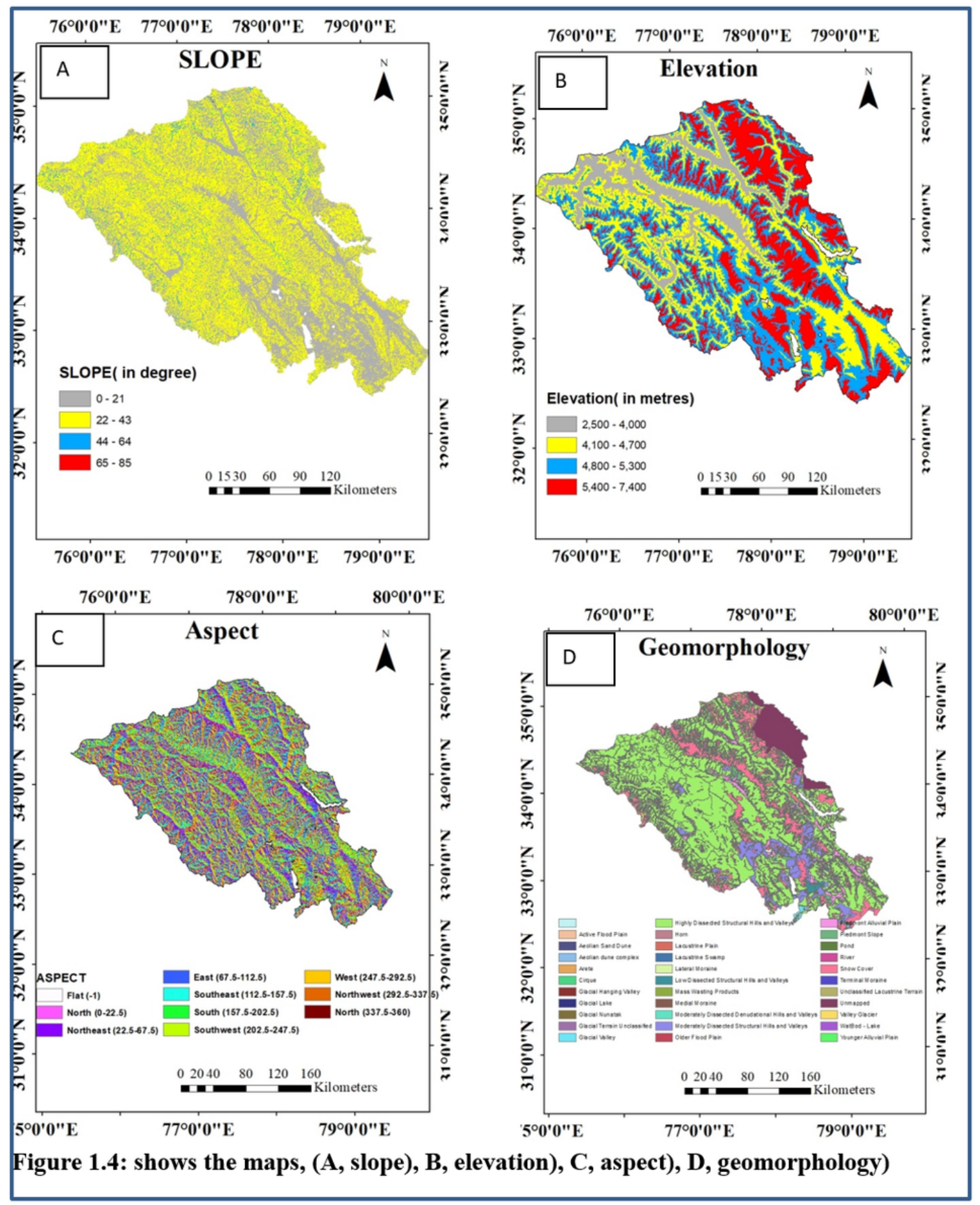

\section{Figure 4}

See image above for figure legend 


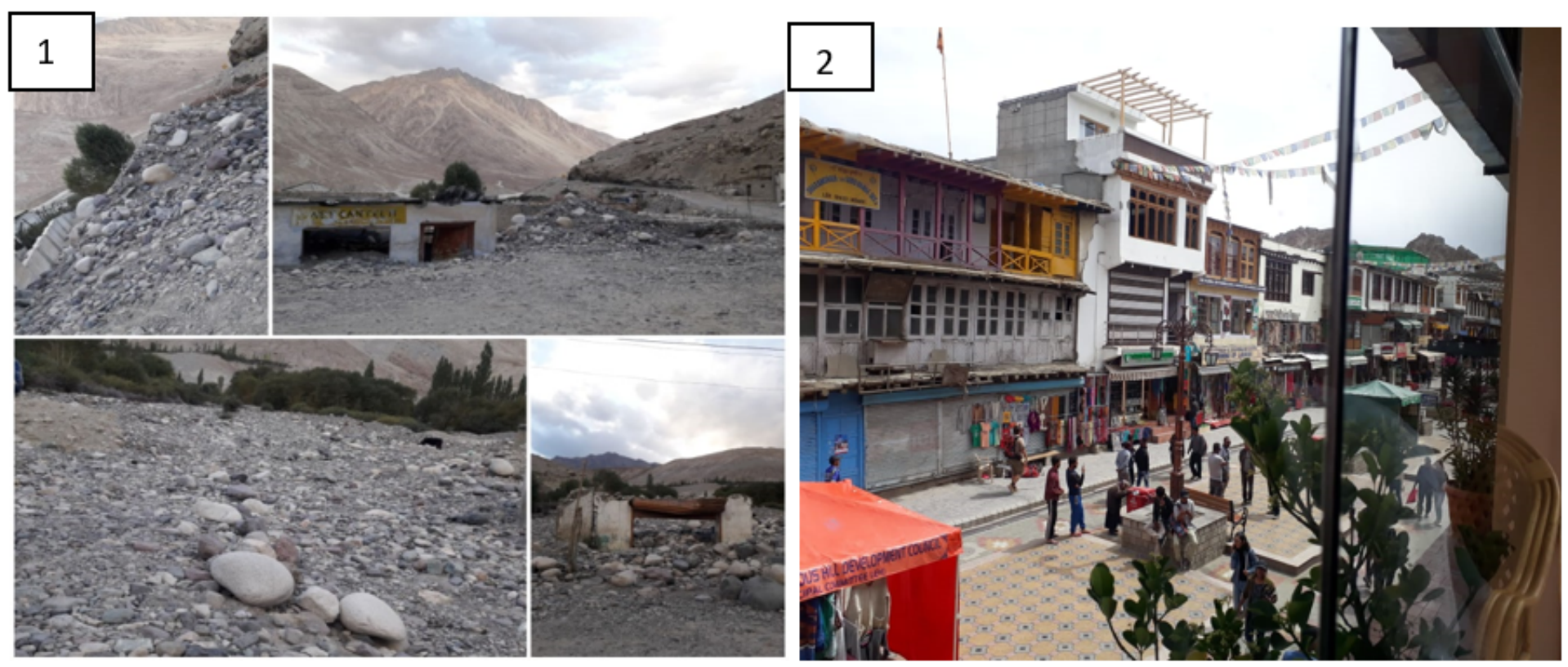

Figure 5

Image.1. Field photograph showing a recent local flash flood incident in Leh region Image.2. Field photograph showing development in construction patterns along with changing life style among the youths (Leh town)
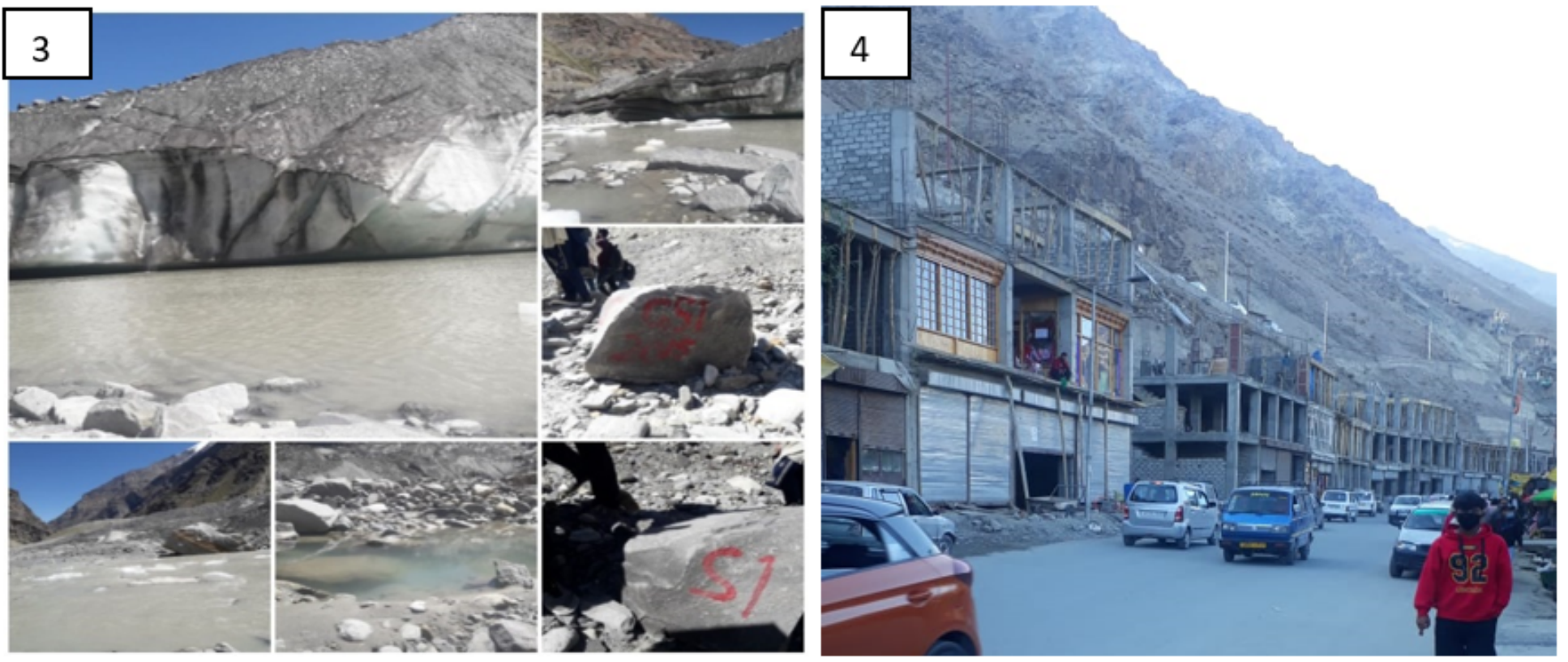

Figure 6

Image.3. Field photograph showing the retreat of Parkachik glacier, kargil Image.4. Field photograph showing haphazard constructions coming along the base of a highly unstable slope (Kargil town) 